\title{
A New Airport in Mexico: Feasibility of Socialist Style Infrastructure in a Private Capital Economy
}

\author{
Budhaditya Mukherjee \\ Autonomous University of Queretaro. Email: budhadityamukherjee2000@gmail.com
}

\begin{abstract}
This paper is based on the positive correlation between projects of infrastructure developed by the government, and the indicators of general well-being of populations in adjoining areas where such constructive changes have been effected. To study the multifactorial effects of the development of a welfare state, we have studied the economic projections associated with the construction of AIFA (Felipe Angeles International Airport), a new airport in Mexico, which was undertaken completely as a government-funded project and developed as a national infrastructure project by the military establishment. Information on projected investments and downstream investments and local employment from the Secretary of Agrarian Development and Tourism (SEDATU) and the Secretary of Public Finances (Forbes) for the new airport AIFA are compared and analyzed with similar projects in other privately developed infrastructure projects and their calculated impact in order to suggest how well-being (achieved through such indices as employment and the generation of micro-enterprises) would pan out for the economy in the State of Mexico, where the new public-funded projects are envisioned. Projections based on available information suggest that the construction of a public infrastructure module can be achieved under economic constraints, focusing on lower spending from the public budget; however, there is a lack of information and transparent policy decisions to indicate growth for entrepreneurs in the local economy, and neither any projected information on opportunities of further private or public investments associated with the airport. A socialist-style public investment project, engineered by the state military, may need more transparency and engagement on behalf of entrepreneurs.
\end{abstract}

Keywords: Mexico, welfare state, new airport, general well-being, micro-enterprises, national infrastructure, privately developed infrastructure, socialist-style public investment project

\section{CONTEXT: STATE AND INVESTMENT RELATIONS}

The plan for this essay is based on an impetus to examine a paradox in the contemporary corporate economy - with reference to a special case study which is likely to have an immediate impact on the socioeconomic trajectory within Mexico's growing investment scenario. The study also offers a model of political decisions and possible efficacies for modern economies. The model studied here may be significant for the evolution of socially engineered (and thus socially responsible) investment models not only in Mexico, or Latin America but also globally for the other countries where the concentration of wealth, and the increasing divide caused by wealth and investment attractions, and thus creating unequal employment opportunities, are a major cause of concern in both wealthy nation-states and in developing and poorer economies. Chen

This Open Access article is published under a Creative Commons Attribution Non-Commercial 4.0 International License (http://creativecommons.org/licenses/by-nc/4.0/), which permits non-commercial re-use, distribution, and reproduction in any medium, provided the original work is properly cited. For citation use the DOI. For commercial re-use, please contact editor@rupkatha.com. 
(2011) suggests that the intervention of the State-controlled infrastructure or investment development often compares unfavorably with the efficiency of private or corporate investments. Public investments, especially as has been seen in socialist contexts, often falls into trap of political favoritism, and this prevents them from being adopted for optimal decisions for well-being (Kahn et al. 20189). A major trend in the last fifty years in the global investment climate has been to create giant interdependent economies with the help of capital derived from largely private funding. This model works efficiently to generate enormous amount of business, social expansion and above all employment resulting from direct investment and growth of auxiliary or downstream sectors of production and consumption (Benlemlih and Bitar 2018). The best models of private (corporate) investment opportunities and benefits resulting from them are visible in China where in spite of communist and highly supervisory governance, which exercises total control over the industry and policy decisions, the industrial policy has adopted strategies with minimum government intervention. This is a typically anti-Marxian trend in socialist economies. The great Shanghai airport project for example, is a result of a controlled private investment policy for infrastructural development. The Shanghai International airport is a privately funded project within a socialist-communist context of governance. Examples of such projects are available from India and Russia where socialist governments have continued to attract foreign and private capital inflows and investments, even from a period prior to open economies and FDI culture of the 1990s.

\section{A CIVIL PROJECT IN THE NEW CAPITALIST STATE OF MEXICO}

An opposite scenario in which a more capitalist form of government and investment climate has promoted more socialistic state funded infrastructural projects is hard to imagine. Infrastructural projects like railway and road development in USA and Germany operate by calling tenders for competitive investment. The newer economic models in the USA and other countries, suggests large private financial interventions instead of direct government payment and funding, as a principal source for development (Hampton 2009). Here, however we shall study a special case from Mexico, where a decidedly open democratic and capital friendly constitution has managed to change its laws to the extent of promoting military and government aided development of public infrastructural projects - like the ongoing Felipe Angeles International Airport, a project involving some 79 billion 972 thousand, or 3.865.043,50 Dollars in international currencies, where a political referendum was mandated to decide of the new airport should be built entirely by the state, cancelling and stalling the construction of a new international airport terminal that was already underway and $25 \%$ complete by the time a new government reversed the decision. This project is an example of a current that goes against such privatization models that are offered in China and India (Wang et al, 2019) The question is of great significance - the success or failure of this project shall determine if there are avenues in contemporary economies of exploring the possibility of involving state agencies, without any intervention from foreign capital and capital manipulations, to give shape to a model that will ultimately reOfuel the economy and create enough opportunities of economic business and activity, and involvement of initiative on a local as well as peripheral frame to generate a climate of well-being and positive social welfare programs. In the National Development Plan that was issued in 2019 under the mandate of Andrés Manuel López Obrador, a member of MORENA (National Regeneration Movement), presidentelect since 2018, it punctually stipulates factors that will derive from the construction of the new 
"Felipe Ángeles" airport. in Mexico City (GOVERNMENT, DM (2019). National Development Plan 2019-2024.). In the National Development Plan that was published on July 12, 2019, entitled "National Development PLAN 2019-2024", contextualities such as the separation of political power from economic power emerge. Under the heading of "Guarantee employment, education, health and well-being", President Andrés Manuel started to work on his projects such as "Sembrando Vida", "Tren Maya" and "Felipe Ángeles" Airport.

\section{INVESTMENT PROBLEMATIC OF STATE PROJECTS}

How do airports impact the welfare state locally and peripherally? The notion that the new international airport first purportedly financed by private houses was corrupt and draining the state's economy manifested in the form of country-wide protests against the government. The conflict of July 11, 2002, between San Salvador Atenco and the federal government reached its climax, after road stoppages (such as the Lechería-Texcoco highway). (Guízar Vázquez 2011, Pena Brandy 2003). On August 6, 2002, the Official Gazette of the Federation released the decree by which the government of President Vicente Fox canceled the project to build the air terminal in the Texcoco region (DOF 08-06-02). Meanwhile, President Peña Nieto, in his second government report (September 2, 2014) announced to revive the works of the Texcoco airport, justifying the cause, with the fact that there was a large increase and saturation of air traffic in the existing old airport of Mexico City. The cost that was estimated at the beginning was 169 thousand million pesos, but finally it shot up to 285 thousand million by the end of 2021 (Milenio news). Socialist President Andrés Manuel López Obrador before taking office as the President of the republic, was firm on his decision to cancel the airport in Texcoco. However, Peña Nieto, announced that private corporations would continue to be built until his term ends (El Universal).

The original plan for the "New Mexico City International Airport", under the mandate of former President Enrique Peña Nieto was started with a hardcore capitalist approach, involving 750 national and international investors. This project was also co-founded with the Energy and Infrastructure Investment Trust, known as FIBRA E. Mainly funded by private company capital, completed $25.01 \%$ of the entire project by the end of the year 2018 (Martínez). This in monetary terms, and according to Gerardo Ruiz Esparza (Former Secretary of Communications and Transport, 2012-2018), writing a BBC news story, reportedly spent a total of 100,000 million pesos by that time. However, Javier Jiménez Esprii, stated that the real cost was around 60,000 million pesos (https://www.bbc.com/mundo/noticias-america-latina-46026759 BBC). In this context, the criticisms that López Obrador received were enough, because he let the same society decide whether to build the airport in Texcoco or not. At the same time, Obrador boasted a new airport construction in Santa Lucia. It was declared that the airport will be built on the military base, and even more so, by the same National Defense Secretariat (Ocampo). The cost of the new airport is estimated at a total cost of 70 thousand 342 million pesos, but the amount of 100 billion pesos would be added for the cancellation of the airport in Texcoco (Sandoval). The problem of my work lies in the investigation of knowing if the construction of the new airport and the new modalities of the "4th Transformation", actually contribute to a better state of well-being, for the participants in the work and for the society of the region (MAZO), or it was just an abrupt decision to build a possibly harmonious society. That said, López Obrador also assured that the contracts of the 
businessmen and their teams will not lose validity, regardless of whether the project for the new airport continues there or is transferred to the Santa Lucía air base. The excess spending from the public purse precipitated a purely political and economic situation. There have been attempts to reduce double spending. For example, the materials and components that were destined for the airport in Texcoco, were presumably reused and re-destined for the Felipe Ángeles Airport. (https://obras.expansion.mx/infraestructura/2020/10/14/texcoco-santa-lucia-material-que-

comparten-los-a Airports). The change in the airport area had economic repercussions, and now the problem was to identify the economic variables that are associated with the construction of a new airport and verify whether, given the geographic conditions of the project, it would actually have any effect on local welfare, either in the near or distant future (Sandoval 2018).

\section{COMPARATIVE ANALYSIS OF SOME DEVELOPMENT MODULES}

The state of research on the alleviation of misery, hunger, poverty, disease and epidemics that contribute to the advancement of society and its well-being can be assessed, as the last 30 years of scrupulous and dedicated research has shown, only on the basis of a multifactorial analysis (CONEVAL). All distinctive aspects of policymakers should also be taken into account, as should many programs focusing on specific micro sections. These investigations are carried out in order to identify, distinguish, prioritize and weigh the needs of vulnerable subjects, who require welfare support for infrastructure industry development projects. Thus, for example, the control of elites, in this country, and their control over economic dynamics, has affected the different welfare plans, which could have been successfully executed throughout history. An investigation from 1973, exposes us the historical reality of a welfare state that was manipulated by bureaucrats (Poitras, 1973). Poitras's article will be a great indicator of the unnecessary contracts that were approved in past governments, and how elite control only favored certain interest groups. The indicators that Poitras uses, he is a facilitator in my project, considering the criticisms he makes when he compares the needs of vulnerable sectors, and how the control of elites has affected their wellbeing. The main argument of the author, based on the context of a study of social empowerment of political personnel who have made decisions under the mandate of Luis Echeverría, president of Mexico (1970 -1976), presumes the intervention of power groups, representing the social security system. Subsequent studies and research have also been directed towards a very similar conclusion. The economic variables that are presented when creating public policies have created a difference in their effectiveness. The goal of a healthy society is to provide pragmatic wellness solutions for populations in need.

On the other hand, the PROGRESA program, founded by President Ernesto Zedillo, in 1997, by virtue of the needs that a welfare program should include, foresees constitutional rights, such as education, and other social rights such as health and nutrition. . The International Food Policy Institute has carried out rigorous research on the operation and validity of the PROGRESA program (1997) and have confirmed the improvements in the aspects foreseen by it in rural communities. In this wellness program, I would like to take advantage of the information on how a program proposed by the government affects, comparing it with a project that is possibly generating jobs. Such projects include the new Santa Lucia airport. It is conjectured that this welfare program (PROGRESA), carried out in Mexico, has represented a paradigm shift, in terms 
of previous programs, and, above all, has a multisectoral approach, which makes it even more complete (Skoufias, 2005). The main argument that is presented is the need to be able to make welfare programs reach the most vulnerable communities, with the help of census takers. Another relevant element of social welfare for my consideration in this article that PROGRESA foresaw was the public infrastructure sector as a public sector industry. The question of the development of a welfare society, attracted by an airport, is merely a causal of the economy. Green's study is a methodology based on geographic studies, taking samples and growth statistics for specific areas, where an improvement in well-being was precisely presumed. This article is very similar to my topic, so your analysis will be useful to me. It is about measuring economic development, with the impact of airports. In Mexico we are facing the same uncertainty, and we will try to use Green's studies to try to interpret a paradigm (Green, 2007). This is investigated by Sheard in a more exhaustive way, and takes into account factors such as the size of an airport. His main argument was to disprove the myth that the well-being of a town depends on the size of an airport. The fact that there is an airport promotes the specialization of certain sectors (mainly aeronautics), but it practically does not generate more jobs. Sheard's discussion is an article that tends to be a bit contrary to my hypothesis, however, his study is quantitative, and also multifactorial, so it is useful to me, although United States parameters have been used for its conclusions (Sheard 2014) . Landing the issue of airports and well-being, Ocampo makes a criticism, and above all a comparison between the advances that have already been made in Texcoco by previous governments, and the new project that is in its initial stages of development in Santa Lucia. This report punctually points out, based on official government figures, the economic catastrophe that was experienced, and also makes interpretations of airport generator projections. The Texcoco airport has had a reputation for being a work of corruption, but the Santa Lucia airport may not be the most viable option. The points that I would like to cover in my research work, such as the economic impact, welfare and industrial development of the area (s), in order to make a comparison, are exposed by Ocampo, and the methodology quantifies, with data from institutions such as INEGI and CONEVAL, they are indispensable a source of legitimate information (Ocampo).

\section{THE NEW AIRPORT OF 2018}

According to an extensive comparative analysis of modules, especially those based on projections for Texcoco, and many others on international airport projects, logistics and data on welfare development due to the industrialization projected for the state of Mexico and the possible economic results of the new airport under the $4^{\text {th }}$ Transformation government, it reflects that the Santa Lucía airport is presumed as a corruption-free project, and an economically sustainable project built with the support of state institutions such as the army, and the secretary of communications and transportation. It really must be checked whether a project implemented by the State is equally beneficial as a project financed by the various private sectors. The effects of the airport will result in industrialization and generation of entrepreneurship projects. Overall, an airport project will do something good for Mexico's national economy. This hypothesis will be supported with data obtained from the Secretary of National Defense, Secretary of Communications and Transportation and Secretary of Agrarian, Territorial and Urban Development. 
The most plausible method to ascertain how an accelerated growth of well-being can develop, is only tentatively suggested in the projections of SEDENA or SEDATU, as well as some journalistic indicators. For example, under the rubric of the projections of the "development plan for the North Zone of the Valley of Mexico and the Santa Lucía airport" (Ministry of Agrarian Development and Tourism), they suggest that the construction of the Felipe Ángeles International Airport will trigger the development of the northern area of the Valley of Mexico, hence the importance of specifying the urban development plans of the municipalities, because "they will allow orderly growth to be given to this entire region of the state, due to the great demand that there will be for services in the area." This projection could be supported with other projects of the same nature. One of these projects I have already mentioned is PROGRESA. Based on models presented by Green, Sheard, PROGRESA (Skoufias, 2005), we can try to confirm that development problems may not adversely affect the prosperity of economic well-being and funds from the federal government, the government of Edo de México, and neighboring states. like Puebla, Querétaro and Morelos, which may experience the secondary effects of this paradigm shift.

\section{CONCLUSIONS}

The projections can only be identified when all information regarding the project are released. So far, the total control rests with SEDENA, the military which constructs and the Secretariat of Defense which will ultimately take decisions regarding how the airport would open out to private sector, large to medium enterprises and how the total business involved at a projected 80 billion pesos (according to President Andrés Manuel/ Munguía, 2021) will help in harnessing a downstream economic welfare. For the development of indicators of any projected growth of the economy the following things will have to be clearly visible:

1. The status of contracts Article 108: The $108^{\text {th }}$ article of the Constitution of Mexico is a reference to a state free of corruption. It refers to the legal responsibility of public servants, such as politicians and presidents, and how they are obliged to present declarations regarding their assets periodically. The second paragraph enlists the legal consequences the President shall face if investigated for fraud, corruption, election crimes and others. In relation to the Project of the New airport in Mexico City, this is highly relevant. The construction and other preparations for the airport, which was being built in Texcoco, were assigned to various private corporations under public government contracts, which were celebrated between the President (as a figure of the State) and these companies. Hence, the government in charge since 2018 may have the legal obligations which would have to be respected by new government.

2. The policy decisions that will foment and crate commercial involvement. Since the private sector involves the question of employment and direct growth of hospitality sectors, business commutation and facilitation, transport, and tourism sectors. The initiation of what Craig Deere calls the civil military collaboration, or the civ-mil collaboration for infrastructure might indeed lead to slowdown, as has been the case in the Soviet block and elsewhere. Moreover, the civil military cooperation enlisted by the new socialist government and the President might create unexpected results in terms of democratic decisions, especially in a 
7 | A New Airport in Mexico: Feasibility of Socialist Style Infrastructure in a Private Capital Economy

country which had a history of military intervention in state politics, mostly to the detriment of all concerned (Deere 2019; Mattiace 2019).

3. The government has left the charge of handling all aspects of the new airport to the military till date. What will be the social implications of such a move if the infrastructural sector is not allowed to mesh in with corporate funding and its imaginative and animated or experimental investment trajectories.

4. Information regarding the scale of investment must be properly understood. Cases against the government of withholding public sector development infrastructure are pending. Here, numerous dynamics or factors of wealth generation and distribution would have to be understood. What kind of geographical, geopolitical, and natural or environmental issues are involved along with a development of a project that seeks to address a common need of the nation.

5. Last but not the least - how will a project such as this influence international opinion and investors.

In conclusion we may say that the resolution of the difficulties in looking at the outputs of this kind of socially binding project will create projection maps for the future - ones that are not only relevant. For divided economies as that of Mexico, but for Latin America and the entire world. There is no doubt that the new airport is the greatest politically relevant project of international significance that has emerged early in the twenty-first century and studying it with more information of parameters is a call for contemporary economics.

\section{References:}

Aldo Munguía. (2021). ¿Y el aeropuerto de Santa Lucía costará menos de 80 mil mdp como dijo AMLO?. El financiero.

Secretaría de Desarrollo Agrario, Territorial y Urbano. (2020). Invertirá Sedatu más de 3 mil mdp en desarrollo integral de municipios aledaños a aeropuerto de Santa Lucía. Gobierno de México.

Forbes staff. (2021). AIFA tiene avance financiero de $80.7 \%$ del monto total: SHCP. Forbes.

Hampton, L. (2009). An introduction to financing airport infrastructure in the USA and elsewhere. Journal of Airport Management, 3(4), 320-327.

Wang, H., Liu, Y., Xiong, W., \& Zhu, D. (2019). Government support programs and private investments in PPP markets. International Public Management Journal, 22(3), 499-523.

Benlemlih, M., \& Bitar, M. (2018). Corporate social responsibility and investment efficiency. Journal of Business Ethics, 148(3), 647-671.

Chen, S., Sun, Z., Tang, S., \& Wu, D. (2011). Government intervention and investment efficiency: Evidence from China. Journal of Corporate Finance, 17(2), 259-271.

Milenio digital. (2021). Derriban estructura del NAIM en Texcoco; continúa su desmantelamiento. Milenio. 
Deare, Craige. Militarization a la AMLO: How Bad Can it Get? Wilson Center. https://www.wilsoncenter.org/sites/default/files/media/uploads/documents/FAQ2022.pdf

Green, R.K. (2007). "Airports and Economic Development", Real Estate Economics, 35, (2007): 91-112.

Kahn, M. E., Sun, W., Wu, J., \& Zheng, S. (2018). The Revealed Preference of the Chinese Communist Party Leadership: Investing in Local Economic Development versus Rewarding Social Connections (No. w24457). National Bureau of Economic Research.

Mattiace, S. (2019). Mexico 2018: AMLO's hour. Revista de ciencia política (Santiago), 39(2), 285.

Poitras, Guy. E. "Welfare Bureaucracy and Clientele Politics in Mexico", Administrative Science Quarterly, vol 18, (1973): 18-26.

Sandoval, M., \& Welp, Y. (2018). Va que vuela: AMLO y la consulta por el aeropuerto.

Sheard, N., "Airports and urban sectoral employment", Journal of Urban Economics, 80, (2014): 133-152.

Skoufias, E., "PROGRESA and its impacts on the welfare of rural households in Mexico", Intl Food Policy Res Inst, vol. 139, (2005). 